\title{
THEORETICAL FOUNDATIONS OF OBTAINING EXTRACTS FROM ANTLERS OF NORTH DEER
}

\author{
Galina Tupkina $^{1}$, Aleksandr Spesivtsev ${ }^{2}$, Kasim Laishev $^{3}$, Nelya Domshenko ${ }^{4}$ \\ ${ }^{1}$ Scientific Research Institute of Agriculture and Ecology of the Arctic, Russia; ${ }^{2}$ A.F.Mozhaisky \\ Military Space Engineering Academy, Russia; ${ }^{3}$ North-West Centre of Interdisciplinary Researches of \\ Problems of Food Maintenance, Russia; ${ }^{4}$ Saint Petersburg State University, Russia \\ sav2050@gmail.com, layshev@mail.ru
}

\begin{abstract}
Reindeer velvet antlers are a valuable raw material for the production of various medicinal products, since they concentrate a whole range of macro- and microelements, amino acids and lipids, hormones and enzymes in reindeer antlers, they can be used as an additional source of nutrients. Practical methods of extracting valuable components from reindeer antlers are not optimal. The losses of velvet antler raw materials due to the immaturity of extraction technology are really heavy. Considering that reindeer antlers are scarce and quite expensive raw materials, their full-scale use is of vital importance. The problem of maximum extraction of valuable components from reindeer antlers by extraction has been posed and solved. At the same time, there has been studied the influence of fineness of grinding of raw materials, temperature and various extraction methods such as maceration, remaceration, percolation, repercolation, etc. Much help in optimizing the extraction parameters is provided by mathematical methods in order to calculate the total extraction efficiency. The preliminary calculations of the efficiency of extraction revealed the best results for extraction processes using velvet antler raw materials of fine grinding, for this reason further calculations were made taking into account the parameters of this fraction. As a result of the experiments, the decisive influence of the extraction stage on the yield of valuable extragents was determined. Thus, with maceration (single-stage extraction) and the ratio of the raw material and the extragent of $1: 11.6$ the efficiency is equal to $86.4 \%$, with three-stage extraction - it is $97.5 \%$, and with four-stage extraction it is $98.4 \%$. It follows that when extracting the velvet antler raw material by the remaceration method the best option is to carry out four extraction stages and use the fine grinding raw material.
\end{abstract}

Key words: reindeer velvet antlers, fineness of raw material grinding, extraction, efficiency.

\section{Introduction}

Over the last 20-30 years unossified reindeer antlers have become widely known both in maral breeding and Northern reindeer herding. The high content of macro- and microelements, amino acids and lipids, hormones and enzymes in reindeer antlers allows them to be used as an additional source of nutrients [1-3].

Practical methods of extracting valuable components from reindeer antlers are not optimal. The losses of velvet antler raw materials due to the immaturity of extraction technology are really heavy. Considering that reindeer antlers are scarce and quite expensive raw materials, their full-scale use is of vital importance [3; 4].

The dynamics and the yield of the extraction of biological raw materials depend on the technological properties of the raw materials, the technological methods of the process and the equipment to be used $[2 ; 5]$.

\section{Methods and materials}

Materials and methods of research. The subject of the research was extracts from reindeer antlers. Reindeer velvet antlers were obtained by cutting off with reindeer being subject to preliminary anesthesia with 0.5 novocaine solution and compliance with aseptic and antiseptic rules. The obtained antlers were preserved by air-thermal drying, they were cleaned of the skin and crushed first on the bone-crusher, then on the mill and then on the UHL-4 vibrator.

To determine the moisture content, the selected samples of velvet antler powder of about $10 \mathrm{~g}$ were weighed and placed in the glass cup preliminarily brought to constant weight. The sample was dried to constant weight with the lid open in a drying oven at $105^{\circ} \mathrm{C}$.

Extraction was carried out with aqueous solutions of ethyl alcohol of various concentrations, when exposed to an ultrasonic field at a frequency of $25 \mathrm{kHz}$ at a temperature of $46-48^{\circ} \mathrm{C}$, first with a $96 \%$ ethyl alcohol for 2.5 hours at an alcohol: raw material ratio of $4: 1$, then with a $70 \%$ solution of ethyl alcohol for 1.5 hours at a ratio of a solution of ethyl alcohol: raw material of $3: 1$, then the 3 rd 
and 4th extractions for 1 hour with solutions of ethyl alcohol of various concentrations at a ratio of ethyl alcohol solutions: raw material of $3: 1$, followed by combining the extracts, acidifying them with acetic acid to $\mathrm{pH}=5.5$; freezing at a temperature of minus 15 to $200{ }^{\circ} \mathrm{C}$ for 48 hours and filtration of the desired product.

\section{Research results}

The properties of the source raw materials exert a decisive influence on the quality of the obtained extracts, therefore, initially the main technological properties of velvet antler raw materials such as moisture content, fineness, raw material absorption of extragent were studied.

The moisture content was calculated by the formula:

$$
X=\frac{m_{1}-m_{2}}{m} 100,
$$

where $m$-weight of the sample, g;

$m_{1}$ - weight of the container with the sample before drying, g;

$m_{2}$ - weight of the container with the sample after drying, g;

$X-$ moisture content, $\%$.

The moisture content in the experimental sample of velvet antler powder of fine grinding amounts to $7.41 \%$, while that of coarse grinding is $7.93 \%$.

The fractional composition of the fined velvet antler raw material was defined by a sieve analysis. To carry out the analysis, the raw material weighed was passed through a series of sieves with gradually decreasing mesh. Then, each fraction was weighed and the average particle size was calculated from the formula [6].

$$
\frac{100}{d}=\sum_{i=1}^{i=k} \frac{\Delta g_{i}}{d_{i}},
$$

where $\Delta g_{i}$ - percentage of raw material pieces in diameter $d_{i}$.

The average particle size of velvet antler raw materials of fine grinding is $0.335 \mathrm{~mm}$, while that of coarse grinding is $1.44 \mathrm{~mm}$.

The absorptivity of the extragent raw material reveals the amount of extragent absorbed by the raw material during the swelling period and after it. This value is auxiliary, when determining the amount of the extragent to be added to the raw material.

The absorption coefficient of the raw material was determined from the formula:

$$
\mathcal{M}=\frac{p_{2}}{p_{1}},
$$

where $m$-absorption coefficient;

$p_{2}$ - weight of the raw material after swelling;

$p_{1}-$ weight of the raw material before swelling.

The absorption coefficient for the velvet antler raw material of fine grinding is 2.40 ; while that of coarse grinding is 3.37 .

Various extraction methods like maceration, remaceration, percolation, repercolation, etc. are used to obtain drugs from biological raw materials.

When extracting dried velvet antler raw materials, the following stages have been observed:

- penetration of the extragent into the raw material;

- soaking of the substances inside the cells;

- dissolution of the substances located on the cell walls or in the form of dried pieces inside the cells, and disposal of the substances from damaged cells and open pores;

- mass transfer of the substances through the porous cell walls by molecular diffusion;

- mass transfer of the substances from the surface of the material to the solution. 


$$
E_{n}=\frac{\left(M^{n}-1\right)}{M^{n}}
$$

If we denote the amount of the extract in the raw material in one unit and express the total amount of extract $M$ in these units, the amount of the extract to be extracted is equal to $(M-1)$. The efficiency of the maceration method is described by the equation, where En is the total efficiency of all the stages; $M$ is the total amount of the extract in parts equal to the amount of the extragent absorbed by the raw material; $\mathrm{n}$ is the number of the extraction stages. We define $M$ :

$$
V=n(M-1) \mathcal{M}
$$

where $V$-total volume of all the extracts;

$M-$ absorption coefficient.

$$
M-1=\frac{V}{n \mathcal{M}} \text { from which } M=\frac{V+n \mathcal{M}}{n \mathcal{M}}=\frac{\frac{V}{n}+\mathcal{M}}{\mathcal{M}} .
$$

All the calculations were performed in the Microsoft Excel program. The calculation results of the M parameter are presented in Table 1.

Results of calculation of the relative value of the total amount of the extract for velvet antler raw materials of a different degree of grinding

\begin{tabular}{|c|c|c|c|}
\hline $\begin{array}{c}\text { Velvet antler raw } \\
\text { materials }\end{array}$ & $\begin{array}{c}\text { Number of } \\
\text { extraction stages, } \boldsymbol{n}\end{array}$ & $\begin{array}{c}\text { Absorption } \\
\text { coefficient, mcp }\end{array}$ & $\boldsymbol{M}$ \\
\hline \multirow{3}{*}{ Fine grinding } & 4 & 2.40 & 2.04 \\
\cline { 2 - 4 } & 3 & 2.40 & 2.39 \\
\cline { 2 - 4 } & 2 & 2.40 & 3.08 \\
\cline { 2 - 4 } & 1 & 2.40 & 5.17 \\
\hline \multirow{4}{*}{ Coarse grinding } & 4 & 3.37 & 1.74 \\
\cline { 2 - 4 } & 3 & 3.37 & 1.99 \\
\cline { 2 - 4 } & 2 & 3.37 & 2.48 \\
\cline { 2 - 4 } & 1 & 3.37 & 3.97 \\
\hline
\end{tabular}

Much help in optimizing the extraction parameters is provided by mathematical methods in order to calculate the total extraction efficiency. During the research, different extraction methods were tested: maceration (one-step extraction), conducted at room temperature; remaceration (multi-stage extraction), performed at the temperature of the "water bath". For these types of extraction, the total extraction efficiency was calculated and optimum parameters of the extraction process were identified.

The preliminary calculations of the efficiency of extraction revealed the best results for extraction processes using velvet antler raw materials of fine grinding, for this reason further calculations were made taking into account the parameters of this fraction.

Applying the above formulas and experimental data, the total remaceration efficiency (four-stage extraction) was calculated (Table 2).

Table 2

Total efficiency of remaceration (multi-stage extraction)

\begin{tabular}{|c|c|c|c|c|}
\hline $\begin{array}{c}\text { Extraction } \\
\text { stage }-\boldsymbol{n}\end{array}$ & $\begin{array}{c}\text { Extragent } \\
\text { volume } \\
\boldsymbol{V}_{\boldsymbol{n}}, \mathbf{m l}\end{array}$ & $\begin{array}{c}\text { Factor of the } \\
\text { remainder of an } \\
\text { extractable substance } \\
\text { in raw material }\end{array}$ & $\begin{array}{c}\text { Aggregate } \\
\text { coefficient of } \\
\text { extraction of a } \\
\text { substance }\end{array}$ & $\begin{array}{c}\text { Total efficiency of } \\
\text { remaceration - } \\
\boldsymbol{E}_{\boldsymbol{n}}, \boldsymbol{\%}\end{array}$ \\
\hline 1 & 120 & 0.395 & 0.605 & 60.5 \\
\hline 2 & 90 & 0.136 & 0.864 & 86.4 \\
\hline 3 & 90 & 0.047 & 0.953 & 95.3 \\
\hline 4 & 90 & 0.016 & 0.984 & 98.4 \\
\hline
\end{tabular}


Using an extragent in the amount indicated in Table 2, the total efficiency of $98.4 \%$ was obtained. With this extraction method, after the 4th stage, $1.6 \%$ of the extractable substance remains. The volume of the extracted extract is $342.6 \mathrm{ml}$. The raw material and the extragent are in the ratio of 1: 11.6.

When performing one-stage extraction with similar parameters of the raw material and extragent, $84.2 \%$ efficiency was obtained (Table 3 ).

Efficiency of maceration (single-stage extraction)

\begin{tabular}{|c|c|c|c|c|}
\hline $\begin{array}{c}\text { Extraction } \\
\text { stage }\end{array}$ & $\begin{array}{c}\text { Extragent } \\
\text { volume }-\boldsymbol{V}, \mathbf{m l}\end{array}$ & $\begin{array}{c}\text { Factor of the } \\
\text { remainder of an } \\
\text { extractable substance } \\
\text { in raw material }\end{array}$ & $\begin{array}{c}\text { Coefficient of } \\
\text { extraction of a } \\
\text { substance from } \\
\text { raw material }\end{array}$ & $\begin{array}{c}\text { Efficiency of } \\
\text { maceration - } \\
\boldsymbol{E}_{\mathbf{1}}, \boldsymbol{\%}\end{array}$ \\
\hline$(1: 10)$ & 300 & 0.158 & 0.842 & 84.2 \\
\hline$(1: 11,6)$ & 348 & 0.136 & 0.864 & 86.4 \\
\hline
\end{tabular}

The relative amount of the total extract ad hoc is $6.33(M=6.33)$. After the extraction in the raw material there remain $15.8 \%$ of the extractable substance. The ratio of the raw material to the extragent is $1: 10$.

With the ratio of the raw material to the extragent $1: 11.6(M=7.34)$, the design efficiency was $86.4 \%$, so $13.6 \%$ of the extractable substance remains in the raw material. To determine the possibility of carrying out an effective extraction process in three stages, the total efficiency for this model was calculated (Table 4).

Total efficiency of three-stage extraction

\begin{tabular}{|c|c|c|c|c|}
\hline $\begin{array}{c}\text { Extraction } \\
\text { number, } \boldsymbol{n}\end{array}$ & $\begin{array}{c}\text { Extragent } \\
\text { volume }- \\
\boldsymbol{V}_{\boldsymbol{n}}, \mathbf{m l}\end{array}$ & $\begin{array}{c}\text { Factor of the remainder } \\
\text { of an extractable } \\
\text { substance in raw material }\end{array}$ & $\begin{array}{c}\text { Aggregate } \\
\text { coefficient of } \\
\text { extraction of a } \\
\text { substance }\end{array}$ & $\begin{array}{c}\text { Total } \\
\text { efficiency of } \\
\text { remaceration - } \\
\boldsymbol{E}_{\boldsymbol{n}}, \boldsymbol{\%}\end{array}$ \\
\hline 1 & 150 & 0.316 & 0.684 & 68.4 \\
\hline 2 & 120 & 0.089 & 0.911 & 91.1 \\
\hline 3 & 120 & 0.025 & 0.975 & 97.5 \\
\hline
\end{tabular}

When calculating the three-stage extraction process, the extragent volumes were calculated to obtain the maximum total remaceration efficiency. The maximum total efficiency is $97.5 \%$. After the third stage $2.5 \%$ of the extractable substance remains in the raw material. The volume of the extracted extract is $342.6 \mathrm{ml}$. The ratio of the raw material to the extragent is $1: 11.7$.

\section{Conclusions}

Thus, as can be seen from the calculations, the maximum total efficiency of $98.4 \%$ is observed, when the four-stage extraction is carried out with the raw material and extragent ratio of 1: 11.6. With the three-stage extraction the efficiency is $97.5 \%$. With maceration (single-stage extraction) and similar parameters of the raw material to the extragent the efficiency was $86.4 \%$. Hence it appears that when extracting the velvet antler raw material by the remaceration method, the best option is to carry out four-stage extraction and use raw materials of fine grinding .

\section{References}

[1] Duved J. The Farminy of Deer World Freundi and modern techniques.-Wellington, 1982, $176 \mathrm{p}$.

[2] Кайзер А.А., Лайшев К.А., Тюпкина Г.И. Биологически активные вещества и экстракты из пантов северных оленей (Biologically active substances and extracts from the reindeer antlers). The Bulletin of The Russian Academy of Agricultural Sciences, 2006, 3, pp. 60-62. (In Russian).

[3] Тюпкина Г.И., Кайзер А.А., Кисвай Н.И., Прокудин А.В. Способы получения биологически активных веществ из пантов северных оленей (Ways of obtaining biologically active 
substances from reindeer antlers). Food resources of the wild and environmental safety of the population. Int. sci. Conf., November 16-18, Kirov, 2004, pp. 179-181. (In Russian).

[4] Ran-Ran Z., Hua-Miao L., Yuan-Chen S., Pan-Yi Z., Ying S., Lei W., Xiu-Mei X. Comparative Proteomic Analysis in Different Growth Stages of Sika Deer Velvet Antler Actaveter.zootechn.sinica, 2016; Vol.47,N 3, pp. 493-50.

[5] Wang Z.; Yang R.-C., Goonewardene L.A., Huedepohl C. Genetic analysis of velvet antler yield in farmed elk (Cervuselaphus), Canad.J.anim.Sc., 1999; Vol.79, N 4, pp. 569-571.

[6] Пономарев В.Д. Экстрагированиелекарственного сырья (Extraction of medicinal raw materials. - M: Medicine, 1976, 204 p. (In Russian). 